\title{
Grain Yield and Biochemical Parameters of Wheat (Triticum aestivum L.) Varieties under Timely and Late Sown Conditions to Assess Thermotolerance
}

\author{
Shital Bangar* and Chetana Mandavia \\ Department of Genetics and Plant Breeding, Junagadh Agricultural University, \\ Junagadh - 362001, India \\ *Corresponding author
}

\section{A B S T R A C T}

\section{Keywords}

Biochemical parameters, gluten, protein, starch, thermo-tolerance, wheat

Article Info

Accepted:

15 February 2020

Available Online:

10 March 2020
A field experiment was carried out in Factorial Randomized Block Design (FRBD) with three replications to assess the thermotolerance in wheat varieties when grown under timely and late sown conditions and to study the biochemical parameters of grains as also their relationship with grain yield. Nine different wheat varieties viz., GW 433, GW 431, HI 1571, GW 432, RAJ 3765, HD 2864, HI 1563, HD 3091 and PBW 670 sown in timely and late sown conditions (i.e., 22 November and 6 December 2012) were included in the study. Late sown varieties were exposed to $32.4^{\circ} \mathrm{C}$ and $33.9-35.3^{\circ} \mathrm{C}$ temperature during flowering and grain filling period as against $29.4^{\circ} \mathrm{C}$ and $30.3-33.3^{\circ} \mathrm{C}$ temperature faced by timely sown wheat. Grain yield was reduced under late sown condition as compared to timely sown wheat. Considering the yield reduction, variety HI 1571 exhibited the least reduction (1.73\%), followed by GW 433(7.90\%) and GW 431 (13.8\%) under late sown condition, whereas variety PBW 670 recorded maximum grain yield reduction $(29.41 \%)$. Gluten content exhibited significant correlation with grain yield but in negative direction. Protein contributed negatively to grain yield whereas, there was non-significant positive correlation between starch and grain yield. The varieties HI 1571, GW 433 and GW 431 could be considered as thermo-tolerant varieties in view of the least reduction in their grain yield under late sown condition. The varieties HI 1571, GW 433 had highest gluten content and GW 433 additionally exhibited high protein as well as starch content under late sown condition,

\section{Introduction}

Wheat (Triticum aestivum L.) is one of the important cereal food crops of the world and consumed by nearly $35 \%$ of the world population and providing $20 \%$ of the total food calories. Wheat consumption is increasing worldwide as a result of higher income levels, urbanization, and substitution with other cereals.

Therefore, the nutritional quality of the wheat whole meal has a significant impact on human health and well-being especially in the developing world. Wheat flour is used for making a large number of products such as 
chapati, bread, biscuit, noodles and pasta. The quality of wheat based foods and the processing of wheat flour dough are strongly related to the composition of proteins and starch. Starch being the major constituent of wheat flour plays an important role as a determinant of food product quality.

Adverse environmental conditions during the anthesis and grain filling period have been identified as a major constraint to wheat quality world-wide $(1,2)$. Within a given location, the strong environmental effects on grain protein content and dough properties can be manipulated by an appropriate choice of sowing time and/or cultivar (3).

Sowing time affects grain protein percentage mainly through its determination of the thermal conditions prevailing during the grain filling period, since late sown material generally flowers late, thereby forcing the grain filling period to coincide with a high temperature $(\mathrm{HT})$ regime.

Extreme temperature during grain filling has been identified as a major source of variation in wheat grain yield and flour quality characteristics (4). For example, a reduction in the duration of the filling period due to HT or drought stress demonstrated a shortened duration of gluten synthesis, which in turn reduced dough strength (5).

Although the grain itself responds directly to high temperatures, the magnitude of the effect on protein and starch accumulation can be modified by altering the source-sink balance through manipulation of the sowing times.

In view if the changing climate condition, it is pertinent to analyse different wheat varieties in order to pinpoint the variety which could perform well and tolerate high temperature when sown late. A number of studies have been undertaken to investigate effect of timely and late sowing on grain yield of high temperature on biochemical parameters and grain yield.

Therefore, this paper seeks to examine the effect of temperature prevailing under timely and late sowing times on grain yield as well as protein, starch and gluten content and to examine the relationship between these biochemical parameters and grain yield.

\section{Materials and Methods}

The experiment was carried out during Rabi 2012-13 at Instructional Farm Krushigadh, Junagadh Agricultural University, Junagadh, India in Factorial Randomized Block Design (FRBD) with three replications. Nine different wheat varieties GW 433, GW 431, HI 1571, GW 432, RAJ 3765, HD 2864, HI 1563, HD 3091 and PBW 670 were sown in timely and late sown conditions (i.e., 22 November and 6 December 2012). The recommended agronomic practices for fertilizer inter-culturing and irrigation were followed.

Grain yield was recorded from the net plot and was exhibited on the hectare basis. Protein, starch and wet gluten contents of wheat grains were determined by Infratec $^{\mathrm{TM}} 1241$ grain analyzer (Foss NIR System INC., Hoganas, Sweden) (6). The statistical analysis of data was carried out by analysis of variance method suggested by Panse and Sukhatme (7).

\section{Results and Discussion}

In wheat, grain filling stage contributes to maximum grain yield (8). In present study, late sown varieties were exposed to $32.4^{\circ} \mathrm{C}$ and 33.9-35. $3^{\circ} \mathrm{C}$ temperature during flowering and grain filling period as against $29.4^{\circ} \mathrm{C}$ and $30.3-33.3^{0} \mathrm{C}$ temperature faced by timely sown wheat.Thus, there was increase in $2^{0}$ - 
$3.6^{\circ} \mathrm{C}$ when the crop was planted in late sown condition. Therefore, the varieties which could sustain their yield level under temperature as high as $35.3^{0} \mathrm{C}$ with the least reduction have been considered as thermotolerant varieties.

\section{Grain yield}

The statistical analysis of the data revealed that sowing time, variety and interaction between D X V significantly affected grain yield per ha (Table 1). Crop sown in timely condition produced the highest (2800.88 $\mathrm{kg} / \mathrm{ha}$ ) grain yield as compared to late sown condition $(2308.63 \mathrm{~kg} / \mathrm{ha})$ reducing the yield to the tune of $25.38 \%$.

Considering the varietal effect, GW 433 was found to be superior $(2699.39 \mathrm{~kg} / \mathrm{ha})$ for this character, however, HD 2864 (2697.11 kg/ha), GW 431 (2688.98 kg/ha), RAJ 3765 (2546.32 kg /ha), HI 1571 (2533.33 kg/ha) and HD $3091(2519.43 \mathrm{~kg} / \mathrm{ha})$ were at par with it. Minimum $(2405.49 \mathrm{~kg} / \mathrm{ha})$ grain yield was noted in variety HI 1563.

Considering the interaction between $\mathrm{D} \mathrm{X} \mathrm{V}$ under timely sown condition (Table 2), HD 2864 gave maximum $(2938.66 \mathrm{~kg} / \mathrm{ha})$ grain yield which was closely followed by GW 431 $(2888.88 \mathrm{~kg} / \mathrm{ha})$ and HD 3091 (2861.11 $\mathrm{kg} / \mathrm{ha}$ ). In late sown condition, maximum $(2588.77 \mathrm{~kg} / \mathrm{ha})$ grain was obtained from GW 433, however, HI 1571 (2511.11kg/ha), GW $431(2489.07 \mathrm{~kg} / \mathrm{ha})$ and HD $2864(2455.55$ $\mathrm{kg} / \mathrm{ha}$ ) were at par with it.

Considering the yield reduction under late sown condition, HI 1571 exhibited the minimum reduction $(1.75 \%)$ followed by GW $433(7.90 \%)$ and GW 431 (13.8\%). Maximum yield reduction was obtained in variety PBW 670 (29.41 \%) under late sown condition. Lak et al., (9) also obtained lower grain yield with delay in sowing due to shorter duration of growth and development. This was also reflected in the work of Aslani and Mehrvar (10), Abid et al., (11) who confirmed that grain yield was reduced as sowing was delayed. The results were in line with Khokhar et al., (12) reported the maximum grain yield with wheat planted in first fortnight of November and any delayed in wheat planting reduced wheat yield.

It might be due to early planted wheat attained maturity in March when mean temperature was around $25^{\circ} \mathrm{C}$ and late planted wheat exposed to higher $\left(32.2^{\circ} \mathrm{C}\right)$ temperature of April. Refay (13) and Ahmed et al., (14) also observed that remarkable reduction in grain yield associated with late sowing as compared with the early sowing. It was may be due to increased temperature $\left(2-4^{0} \mathrm{C}\right)$ at the time of grain filling period in late sowing condition.

One of the main reasons for reduced yield is the decreased in plant water status due to excessive water loss through rapid transpiration caused by high temperature Kumar et al., (15). Exposure of late sown crop to high temperature during reproductive growth stage also reduces grain filling period and remobilization of photosynthates to developing grains which reduces grain yield Fisher (16). Thus varieties HI 1571, GW 433 and GW 431 could be considered as thermotolerant varieties in view of the least reduction in their grain yield under late sown condition.

\section{Protein content}

Proteins are the most important components of wheat grains governing end-use quality. Both amount and composition of protein determine the protein quality and hence end use quality of wheat. It is evident from the data that sowing time (D), variety $(\mathrm{V})$ and interaction between $\mathrm{D} X \quad \mathrm{~V}$ significantly influenced protein content. Protein content 
was significantly higher $(14.59 \%)$ in timely sowing as compared to late sowing (14.24\%) condition (Table 1).

Considering the varietal effect, PBW 670 was significantly superior (15.95\%) over other varieties followed by HD 3091 (14.87\%) and HI 1563 (14.63\%). Variety GW 431 recorded minimum $(13.75 \%)$ protein content.

In timely sown condition (Table 2), the highest (15.77\%) protein content was recorded in PBW 670 which was statistically identical to HD 3091 (15.33 \%). The lowest $(13.93 \%)$ protein content was found in GW 431. Under late sown condition, PBW 670 $(16.13 \%)$ retained the first position followed by GW 433 (14.47\%). GW 431 (13.57\%) exhibited minimum protein content.
The results are in agreement with those obtained by Hozayn et al., (17) who reported that protein content in grains of wheat significantly reduced by heat treatment. Shahzad et al., (18) also observed similar results. The delay of sowing dates exposed the crop to high temperature stress during different developmental processes as compared with those sown at normal date.

The decreased protein content during late sowing could be attributed to the disruption of normal protein synthesis under high temperature stress. Variety PBW 670 could maintain protein content under late sown condition, suggesting the least denaturation of protein.

Table.1 Effect of sowing dates on grain yield and biochemical parameters of wheat varieties under timely and late sown conditions

\begin{tabular}{|c|c|c|c|c|}
\hline Treatment & $\begin{array}{c}\text { Grain Yield } \\
\text { (Kg/ha) }\end{array}$ & $\begin{array}{c}\text { Protein Content } \\
(\%)\end{array}$ & $\begin{array}{c}\text { Starch Content } \\
(\%)\end{array}$ & $\begin{array}{c}\text { Gluten Content } \\
(\%)\end{array}$ \\
\hline \multicolumn{5}{|l|}{ Sowing Time (D) } \\
\hline Timely $\left(D_{1}\right)$ & 2800.88 & 14.59 & 61.79 & 29.31 \\
\hline Late $\left(\mathrm{D}_{2}\right)$ & 2308.63 & 14.24 & 62.01 & 30.35 \\
\hline S.Em. \pm & 33.39 & 0.06 & 0.07 & 0.09 \\
\hline C.D. at $5 \%$ & 100.10 & 0.19 & 0.21 & 0.27 \\
\hline \multicolumn{5}{|l|}{ Variety (V) } \\
\hline GW $433\left(V_{1}\right)$ & 2699.39 & 14.45 & 62.05 & 29.80 \\
\hline GW $431\left(V_{2}\right)$ & 2688.98 & 13.75 & 62.10 & 29.25 \\
\hline HI $1571\left(V_{3}\right)$ & 2533.33 & 14.35 & 61.92 & 30.07 \\
\hline GW $432\left(V_{4}\right)$ & 2486.11 & 13.87 & 62.07 & 29.67 \\
\hline RAJ $3765\left(V_{5}\right)$ & 2546.32 & 14.03 & 62.03 & 29.55 \\
\hline HD $2864\left(V_{6}\right)$ & 2697.11 & 13.82 & 62.50 & 29.45 \\
\hline HI $1563\left(V_{7}\right)$ & 2405.49 & 14.63 & 61.77 & 29.88 \\
\hline HD $3091\left(V_{8}\right)$ & 2519.43 & 14.87 & 61.53 & 31.08 \\
\hline PBW $670\left(V_{9}\right)$ & 2416.66 & 15.95 & 61.10 & 29.70 \\
\hline 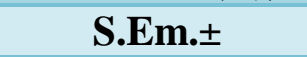 & 70.83 & 0.13 & 0.15 & 0.19 \\
\hline C.D. at $5 \%$ & 212.35 & 0.40 & 0.44 & 0.58 \\
\hline \multicolumn{5}{|l|}{ DxV } \\
\hline S.Em. \pm & 100.17 & 0.19 & 0.21 & 0.27 \\
\hline C.D. at $5 \%$ & 300.31 & 0.57 & 0.63 & 0.82 \\
\hline C.V. \% & 6.79 & 2.28 & 0.59 & 1.59 \\
\hline
\end{tabular}


Table.2 D x V interaction for grain yield and biochemical parameters of wheat varieties under timely and late sown conditions

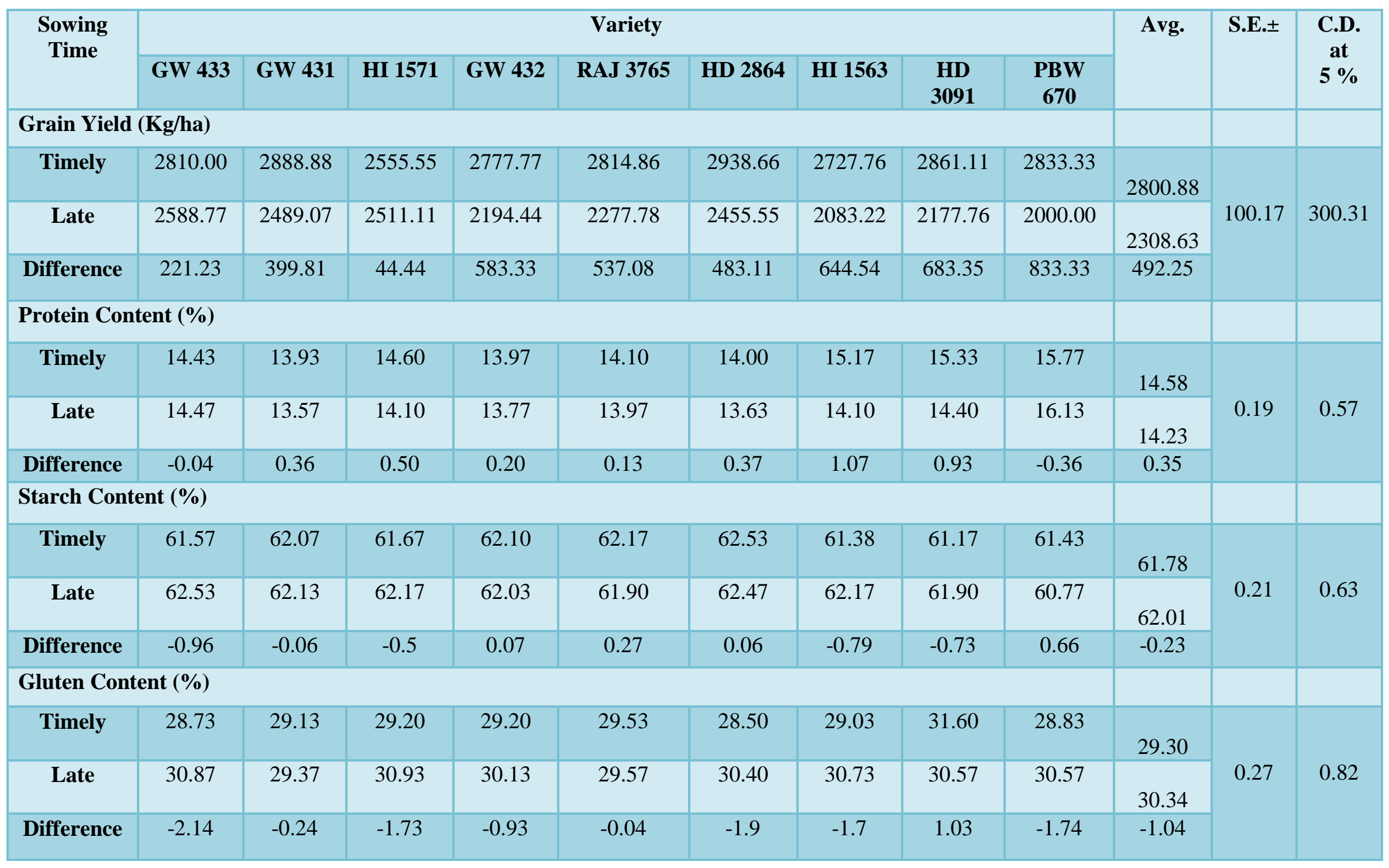


Table.3 Correlation coefficient (' $r$ ' values) between grain yield and biochemical parameters of wheat varieties under timely and late sown conditions

\begin{tabular}{|c|c|c|}
\hline Sr. No. & Parameters & $\begin{array}{c}\text { Correlation coefficient ('r' value) } \\
\text { with grain yield }\end{array}$ \\
\hline $\mathbf{1}$ & Protein content & -0.0013 \\
\hline $\mathbf{2}$ & Starch content & 0.1195 \\
\hline $\mathbf{3}$ & Gluten content & $-0.4680 *$ \\
\hline
\end{tabular}

* Correlation significant at the 5\%.

\section{Starch content}

Sowing time with respect to starch content was statistically significant; however, starch content under late sown condition was higher $(62.01 \%)$ as compared to timely sown condition (61.79\%) (Table.1). Varieties as well as interaction between $\mathrm{D} \mathrm{X} \mathrm{V}$ also showed significant differences. Considering the varietal effect, HD $2864(62.50 \%)$ was the best with respect to starch content, however, GW $432(62.07 \%)$ was at par with it. Under timely sown condition, HD 2864 recorded maximum $(62.53 \%)$ starch content (Table 2). RAJ 3765 (62.17 \%), GW 432 $(62.10 \%)$ and $\mathrm{GW} 431(62.07 \%)$ were at par with it.

In late sown condition, GW 433 exhibited higher $(62.53 \%)$ starch content followed by HD $2864(62.17 \%)$. Variety, PBW 670 $(60.77 \%)$ exhibited the lowest starch content. This finding corroborates the results obtained by Hozayn et al., (17) and Hakim et al., (19), who found that the percentage of starch increased under late sowing condition.

The results are not in agreement with Balla et al., (5) who studied the quality of winter wheat in relation to heat stress, where they reported that the starch content was significantly influenced by sowing time and genotypes; it was higher under optimum sowing date. The findings of Kumar et al., (15) are in contrast to the present findings, where they reported decrease in starch content in response to heat stress in wheat cultivars under investigation. Variety GW 433 and HD 2864 could be labelled as thermo-tolerant, as they could sustain starch content under late sown condition.

\section{Gluten content}

Gluten content reflects nutritional and baking quality of wheat. High temperature is capable of causing substantial changes in the accumulation level of gluten during grain filling. Grain gluten content is the most important parameter determining wheat quality. Statistical analysis of data revealed that sowing time, variety and interaction between D X V affected gluten content.

The highest gluten content (30.35\%) was recorded for crop planted under late sown condition (Table 1), and decreased gluten content was found in timely sown condition $(29.31 \%)$. Among different varieties, variety HD 3091 (31.08\%) proved to be the best, however, HI $1571(30.71 \%)$ was at par with it. Variety GW 431 exhibited minimum $(29.25 \%)$ gluten content.

Considering the interaction between $\mathrm{D} \mathrm{X} \mathrm{V}$ under timely sown condition (Table 2), HD 3091 exhibited higher $(31.60 \%)$ gluten content followed by RAJ 3765 (29.53\%). In late sown condition, again HI 1571 (30.93\%) was the best with respect to gluten content, 
however, GW 433 (30.87 \%), HI 1563 (30.73 \%), HD 3091 (30.57 \%), PBW 670 (30.57\%), HD 2864 (30.40 \%) and GW 432 (30.13\%) also fared better and were at par with it.

The finding of this study is in agreement with Torbica and Mastilovic (20) who obtained higher gluten content in late sown condition and reported that temperature affected the amount, composition and polymerisation of gluten content.

Sowing wheat at late date significantly increased the content of wet gluten as reported by Klupczynski et al., (21) and Podolska and Stankowski (22). The results are in contrast with Yasmin et al., (23) and Balla et al., (5) who reported reduction in gluten content under delayed sowing.

\section{Correlation coefficient analysis}

Correlation coefficient revealed that there was significant correlation between grain yield and gluten content $(-0.4680 *)$ but in negative direction. Protein content (-0.0013) showed negative non-significant correlation with grain yield, whereas, starch content (0.1195) showed positive correlation with grain yield although, it was non-significant (Table 3). Shahzad et al., (18) also reported the same result. Hussain et al., (24), while analysing the correlation of some qualitative and quantitative traits with grain yield of wheat, reported negative and significant correlation between grain yield and gluten content. Brill et al., (25) examined the comparison of grain yield and grain protein concentration of commercial wheat varieties. They reported that there was a negative correlation between grain yield and protein content.

The study showed that there was reduction in grain yield of wheat under late sown condition compared to timely sown condition. Considering grain yield performance,
HD 2864, GW 431 and HD 3091 showed an increase in grain yield under timely sown condition, while GW 431, GW 433 and HI 1571 fared better under late sown condition with respect to grain yield. Considering yield reduction under late sown condition, HI 1571 (1.73\% reduction), GW $433 \quad$ (7.90\% reduction) and GW 431 (13.8\% reduction) showed minimum yield reduction compared to other varieties. Thus, they could be considered as thermo-tolerant varieties. Biochemical parameters showed significant differences with respect to protein, starch and gluten content. Gluten content exhibited significant negative correlation with grain yield. Protein contributed negatively to grain yield, whereas, there was non-significant positive correlation between starch and grain yield.

Thus, it could be concluded that thermotolerant varieties, HI 1571 and GW 433 also had higher grain gluten content, making their grain quality favourable for chapatti making. Additionally, variety GW 433could be labelled as the best variety with increased protein and starch content wheat sown late.

\section{References}

1. Jiang, D., Yue, H., B. Wollenweber, W. Tan, W. Mu \& Y. Bo (2009). Effect of post- anthesis drought and waterlogging on accumulation of high molecular weight glutenin subunits and glutenin macropolymers content in wheat grain. Journal of Agronomy and Crop Science, 195: 89-97.

2. Wardlaw, I. F. (1994). The response of wheat to high temperature following anthesis. I. The rate and duration of kernel filling. Australian Journal of Plant Physiology, 21: 731-739.

3. Motzo, R., S. Fois and F. Giunta (2007).Protein content and gluten quality of durum wheat (Triticum turgidum 
subsp.durum) as affected by sowing date. J. Sci. Food and Agril., 8: 1480-1488.

4. Labuschagne, M. T., O. Elago \& E. Koen (2009). The influence of temperature extremes on quality and starch characteristics in bread, biscuit and durum wheat.Cereal Chemistry, 86: 61-66.

5. Balla, K. and Veisz, O. (2007). Changes in the quality of cereals in response to heat and drought stressActa Agronomica Óvariensis49: 451-453.

6. Oak, M. D., R. M. Patil, D. N. Bankar, J. H. Bhagwan, A. L. Bipinraj, S. A. Tamhankar, B. K. Honrao \& S. C. Misra (2011). Performance of durum wheat lines for quality and rust resistance. $J$. Wheat Res., 3(1): 71-72.

7. Panse, V.G. and P. V. Sukhatme (1985). Statistical Methods for Agricultural Workers. I.C.A.R. Pub., New Delhi.

8. Larson, H. \& A. C. Eliasson (1997). Influence of the starch granule surface on the rheological behavior of wheat flour dough. Journal of Texture Studies, 28: 487-501.

9. Lak M., A. Farnia and M. Shaban (2013). Effect of different sowing dates on yield components of wheat (Triticum aestivum L.) cultivars in lorestan provience, Iran. Adv. Agri. Boil., 1(4): 89-93.

10. Aslani F. and M. R. Mehrvar (2012). Responses of wheat genotypes as affected by different sowing dates. Asian J. Agri. Boil., 1(4):89-93.

11. Abid, M., S. Ali, L.K. Qi, R. Zahoor, Z. Tian, D. Jiang, J. L. Snider and T Dai (2018). Physiological and biochemical changes during drought and recovery periods at tillering and joining stages in wheat (Triticum aesticum L.), Sci.RepUK., 8(1):4615.

12. Khokhar Z., I. Hussain, B. khokhar and M. Sohail (2010). Effect of planting date on yield of wheat genotypes in sindh. Pak. $J$. Agric. Res., 23(3-4): 103-107.

13. Refay Y. A. (2011). Yield and yield component parameters of bread wheat genotypes as affected by sowing dates. Middle-East J. Sci. Res., 7(4): 484-489.

14. Ahmed, M., M. A. Aslam, F. Hassan,R. Hayat and S. Ahmad (2019). Biochemical, physiological and agronomic response of wheat to changing climate of rainfed Pakistan. Pak. J. Bot., 51(2): 1-17.

15. Kumar, S., Alam, P. and Ali, N. (2013). Response of wheat (Triticum aestivum $\mathrm{L}$. emed. Fori and Paol.) varieties to sowing dates. J. Res., 25(1): 56-59.

16. Fisher R. A. (2007). Understanding the physiological basis of yield potential in wheat J. Agric. Sci., 145: 99-113.

17. Hozayn, M., Abd El-Monem, A. A., Ebtihal, Abd El-Hameed and Tawfik, M. M. (2012).Mitigating global warming impact on wheat productivity in Egipt. Aus. J. Bas. App. Sci., 6(10): 525-531.

18. Shahzad, M. A., Wasi-ud-din, Sahi, S. T., Khan, M. M., Ehsanullah and Ahmad, M. (2007). Effect of sowing dates and seed treatment on grain yield and quality of wheat. Pak. J. Agri. Sci., 44(4): 581-583.

19. Hakim M. A., A. Hussain, JAT. Silva, V. O. Zvolinsky and M. M. Khan (2012). Yield, protein and starch content of twenty wheat (Triticum aestivum L.) genotypes exposed to high temperature under late sowing conditions. J. Sci. Res., 4: 477489.

20. Torbica, A. \& J. Mastilovic (2008). Effect of wheat bug (Eurygaster Spp. And Aelia Spp.) infestation in pre harvest period on wheat technological quality and gluten comppsition. Food Processing, Quality and Safety, 35: 47-52.

21. Klupczynski, Z., Knapowski, T., Ralcewicz, M. and Murawska, B. (2000). Effect of varied nitrogen fertilization on the technological value of bread making winter wheat cultivars. Fertilizerz and Fertilization, 3(4): 61-72.

22. Podolska, G. and Stankowski, S. (2001). Yielding and winter wheat grain quality 
depending on the sowing rate and nitrogen fertilizer dose. Biul.IHAR, 204: 163-167.

23. Yasmin, S., Ahmad, Z., Akhtar, N., Mustafa, Z. Mujahid, M. Y. and Kisana, N. (2008). Manifestation of some wheat quality attributes at normal and late planting under raifed conditions. Pak. $J$. Agric. Res., 21(1-4): 1-6.

24. Hussain, M., Khan, A. S., Khaliq, I. and
Maqsood, M. (2012). Correlation studies of some qualitative and quantitative traits with grain yield in spring wheat across two enviroments. Pak. J. Agri. Sci., 49(1): 1-4.

25. Brill, R.; Gardner, M.; Fettell, N. and McMullen, G. 2012. Comparison of grain yield and grain protein concentration of commercial wheat varieties. Buigarian $J$. Agril. Sci., 1-8.

\section{How to cite this article:}

Shital Bangar and Chetana Mandavia. 2020. Grain Yield and Biochemical Parameters of Wheat (Triticum aestivum L.) Varieties under Timely and Late Sown Conditions to Assess Thermotolerance. Int.J.Curr.Microbiol.App.Sci. 9(03): 1949-1957. doi: https://doi.org/10.20546/ijcmas.2020.903.227 